\author{
o. Tomasz Krzesik OMI ${ }^{1}$ \\ Uniwersytet Papieski Jana Pawła II w Krakowie
}

\title{
Odwiedziny domowe jako okazja do głoszenia Ewangelii Chrystusa
}

W dobie rozwoju środków komunikacji coraz częściej rodzi się pytanie o to, na ile nowoczesne sposoby i narzędzia komunikacyjne pomagają w budowaniu międzyludzkich relacji. Wydaje się, że człowiek przy pomocy nowoczesnych narzędzi komunikacyjnych nie potrafi niczym zastąpić czegoś bardzo fundamentalnego w relacjach międzyludzkich, a mianowicie spotkania. Nietrudno zauważyć, że codzienność życia rodzinnego woła o możliwość spotkania. Wielokrotnie domownicy mijają się, podążając do swoich obowiązków. Bywają jednak chwile, w których członkowie rodziny spotykają się razem, i to w kontekście wiary. Katalizatorem takich spotkań są odwiedziny duszpasterza w rodzinie. Owe odwiedziny nie zawsze przybierają charakter oficjalnej wizyty duszpasterskiej. Zawsze jednak stwarzają okazję do spotkania w klimacie wiary i ożywienia bliskości Jezusa Chrystusa.

W tym artykule podjęta zostanie refleksja nad możliwością głoszenia Ewangelii w kontekście domowych odwiedzin, które będą nazywane

1 Ojciec Tomasz Krzesik, misjonarz oblat Maryi Niepokalanej jest doktorem teologii, homiletą. Obecnie mieszka w Ottawie, gdzie pełni posługę duszpasterską jako proboszcz polonijnej parafii Świętego Jacka Odrowąża. W 2017 roku obronił doktorat na uniwersytecie Papieskim Jana Pawła II. Jego poszukiwania naukowe to prawdy eschatologiczne w przepowiadaniu, ze szczególnym uwzględnieniem przepowiadania o czyśćcu. E-mail: tkrzesik@gmail.com. 
spotkaniem. Zagadnienie zostanie opracowane przez odwołanie się najpierw do tradycji wizyty duszpasterskiej znanej jako „kolęda”. Na kolejnym etapie zwrócimy uwagę na kilka miejsc w Biblii, a następnie w życiorysach świętych, w których mamy do czynienia z odwiedzinami domowymi, a tym samym ze spotkaniem. W dalszej części refleksji omówione zostaną przestrogi, czym odwiedziny domowe nie powinny być. $\mathrm{Na}$ koniec podjęta zostanie próba zarysowania metodologii odwiedzin domowych.

\section{Tradycja wizyty duszpasterskiej w okresie Bożego Narodzenia}

Średniowieczny zwyczaj odwiedzania wiernych bierze swą potoczną nazwę „kolęda” od łacińskiego terminu calendae (pierwszy dzień miesiąca). Założeniem kolędy było stworzenie sytuacji ewangelizacyjnej i nawiązanie bliższych relacji pomiędzy duszpasterzem i wiernymi ${ }^{2}$. Na różnych etapach historycznego rozwoju wizyta duszpasterska pełniła najpierw rolę okazji do pobierania opłaty za pełnioną wobec wiernych posługę duszpasterską, wykorzeniania praktyk zabobonnych i edukowania w kwestiach podstawowego katechizmu ${ }^{3}$. Kolęda jako narzędzie ewangelizacyjne była propagowana przez różne lokalne synody kościelne, z których najbardziej kluczowe są uchwały synodu prowincjalnego w Piotrkowie z 1607 roku. Upowszechniły się też w poszczególnych diecezjach zalecenia dotyczące kolędy zawarte w Epistola pastoralis - liście napisanym w 1601 roku przez prymasa Bernarda Maciejowskiego. Dokument ten, zwany Pastoralna Maciejowskiego, jak również uchwały synodu w Piotrkowie zyskały zatwierdzenie Stolicy Apostolskiej, co przyczyniło się do ich skuteczniejszego rozpowszechniania ${ }^{4}$. Zalecenia obowiązujące w niektórych diecezjach nakazywały w czasie kolędy odwiedzanie

2 Por. R. Kamiński, Kolęda, w: Leksykon teologii pastoralnej, red. R. Kamiński, W. Przygoda, M. Fiałkowski, Lublin 2006, s. 384.

3 Por. R. Kamiński, Kolęda, dz. cyt., s. 384-385.

4 Por. R. Kamiński, Kolęda, dz. cyt., s. 384. 
innowierców ${ }^{5}$. Współcześnie obowiązujący w Kościele Kodeks prawa kanonicznego zaleca proboszczowi poznanie wiernych i odwiedzanie rodzin, aby dzielić ich życiowe doświadczenia 6 .

\section{Odwiedziny domowe w Biblii i życiu świętych}

Na uwagę zasługuje kilka miejsc w Piśmie Świętym, gdzie jest mowa o spotkaniu, tudzież odwiedzinach domowych. Jezus odwiedził dom Szymona, był w gościnie u Zacheusza, czy też przybył do domu Łazarza, którego domownicy opłakiwali jako zmarłego. Przywołamy poniżej dwa miejsca biblijne: rozmowę Jezusa z uczniami idącymi do Emaus oraz zaproszenie apostołów do domu Lidii. Następnie zaś omówimy dwa przykłady z życia świętych: spotkanie św. Scholastyki z jej bratem św. Benedyktem oraz obiady ze św. Janem Pawłem II.

\subsection{Rozmowa Jezusa z uczniami idącymi do Emaus}

Jezus przyłącza się do idących do Emaus uczniów. Na początku identyfikują go jako nieznajomego. To pasjonujące spotkanie pokazuje, jak Chrystus pomaga im zinterpretować to, co dzieje się w tym momencie w ich życiu w świetle słowa Bożego. Stwarza atmosferę otwartości i przyjaźni. Uczniom było dobrze w tej atmosferze, co owocuje zaproszeniem nieznajomego do domu. W domu uczniowie odkrywają owoc Jezusowej ewangelizacji. W nieznajomym towarzyszu drogi spotykają Jezusa i po pewnym czasie rozpoznają go.

Tego samego dnia dwaj z nich byli w drodze do wsi, zwanej Emaus, oddalonej sześćdziesiąt stadiów od Jerozolimy. Rozmawiali oni z sobą o tym wszystkim,

5 Por. P. Janowski, Kolęda, wizyta duszpasterska, w: Encyklopedia katolicka, t. 9, red. A. Bednarek i in., Lublin, s. 349.

6 „Pragnąc dobrze wypełnić funkcję pasterza, proboszcz powinien starać się poznawać wiernych powierzonych jego pieczy. Winien zatem nawiedzać rodziny, uczestnicząc w troskach wiernych, zwłaszcza w niepokojach i smutku, oraz umacniając ich w Panu, jak również - jeśli w czymś nie domagają - roztropnie ich korygując", Kodeks prawa kanonicznego, Poznań 1984, kan. 529 §1. 
co się wydarzyło. Gdy tak rozmawiali i rozprawiali z sobą, sam Jezus przybliżył się i szedł z nimi. Lecz oczy ich były niejako na uwięzi, tak że Go nie poznali. On zaś ich zapytał: „Cóż to za rozmowy prowadzicie z sobą w drodze?” Zatrzymali się smutni. A jeden z nich, imieniem Kleofas, odpowiedział Mu: „Ty jesteś chyba jedynym z przebywających w Jerozolimie, który nie wie, co się tam w tych dniach stało”. Zapytał ich: „Cóż takiego?” Odpowiedzieli Mu: „To, co się stało z Jezusem Nazarejczykiem, który był prorokiem potężnym w czynie i słowie wobec Boga i całego ludu; jak arcykapłani i nasi przywódcy wydali Go na śmierć i ukrzyżowali. A myśmy się spodziewali, że On właśnie miał wyzwolić Izraela. Tak, a po tym wszystkim dziś już trzeci dzień, jak się to stało. Nadto jeszcze niektóre z naszych kobiet przeraziły nas: były rano u grobu, a nie znalazłszy Jego ciała, wróciły i opowiedziały, że miały widzenie aniołów, którzy zapewniają, iż On żyje. Poszli niektórzy z naszych do grobu i zastali wszystko tak, jak kobiety opowiadały, ale Jego nie widzieli”. Na to On rzekł do nich: „O nierozumni, jak nieskore są wasze serca do wierzenia we wszystko, co powiedzieli prorocy! Czyż Mesjasz nie miał tego cierpieć, aby wejść do swej chwały?” I zaczynając od Mojżesza poprzez wszystkich proroków wykładał im, co we wszystkich Pismach odnosiło się do Niego. Tak przybliżyli się do wsi, do której zdążali, a On okazywał, jakoby miał iść dalej. Lecz przymusili Go, mówiąc: „Zostań z nami, gdyż ma się ku wieczorowi i dzień się już nachylił”. Wszedł więc, aby zostać z nimi. Gdy zajął z nimi miejsce u stołu, wziął chleb, odmówił błogosławieństwo, połamał go i dawał im. Wtedy oczy im się otworzyły i poznali Go, lecz On zniknął im z oczu (Łk 24, 13-35).

W bardzo ciekawy sposób interpretowane jest udzielenie gościny nieznajomemu przez uczniów. Dopiero gdy okażą gościnność nieznajomemu, mogą zrozumieć Boży plan7 . Istotna w warstwie interpretacyjnej jest także sprawa posiłku, który Jezus spożywa z uczniami. Posiłek symbolizuje nadejście królestwa Bożego ${ }^{8}$.

Ten fragment jest ciekawy o tyle, że podpowiada nam pewną metodologię odwiedzin domowych. Chociaż opowiedziane w pierwszej części wydarzenie nie jest odwiedzinami domowymi, to na pewno jest spotkaniem. W ostatniej części to szczególne spotkanie przybiera formę odwiedzin domowych. Warto zauważyć, że nieznajomy Rozmówca uczniów buduje bardzo dobrą nić porozumienia, relacji, stwarza atmosferę korzystną do wyjaśnienia wydarzeń przez pryzmat paschalnego misterium ukrzyżowania i zmartwychwstania. To ważny metodologicznie element.

7 Por. Katolicki komentarz biblijny, red. R. E. Brown, J. A. Fitzmyer, R. E. Murphy, red. nauk. wyd. pol. W. Chrostowski, Warszawa 2001, s. 1105.

8 Por. Katolicki komentarz biblijny, dz. cyt., s. 1106. 
Innym istotnym elementem jest głoszenie słowa Bożego w sytuacji egzystencjalnej, w jakiej znaleźli się uczniowie. To właśnie głoszenie i wyjaśnianie przez Jezusa tekstów odnoszących się do Mesjasza, jak również Jego gesty czynione wobec uczniów sprawiły, że rozpoznali Go; w istocie miało miejsce bardzo osobliwe spotkanie z Jezusem

\subsection{Zaproszenie Apostołów do domu Lidii}

Inny charakter niż spotkanie uczniów idących do Emaus z Jezusem miało spotkanie apostołów z Lidią z Tiatyry. Było ono właściwie owocem ewangelizacji Pawła w Filippi, jednym z głównych miast Macedonii (por. Dz 16, 12). Lidia chciała bardziej poznać sprawy, o których opowiadał Apostoł, dlatego wywarła wpływ na Pawła i na towarzyszących mu Sylasa i Tymoteusza, aby zatrzymali się w jej domu. Autor Dziejów Apostolskich opisał to spotkanie następująco:

Przysłuchiwała się nam też pewna „bojąca się Boga” kobieta z miasta Tiatyry imieniem Lidia, która sprzedawała purpurę. Pan otworzył jej serce, tak że uważnie słuchała słów Pawła. Kiedy została ochrzczona razem ze swym domem, poprosiła nas: „Jeżeli uważacie mnie za wierną Panu - powiedziała - to przyjdźcie do mego domu i zamieszkajcie w nim!". I wymogła to na nas (Dz 16, 14-15).

Interpretatorzy tego fragmentu Dziejów Apostolskich podkreślają, że gościnność Lidii jest przykładem sukcesu wczesnochrześcijańskiej misji domowej ${ }^{10}$. Po wysłuchaniu chrześcijańskiego orędzia Lidia została ochrzczona i zaoferowała swój dom na mieszkanie dla apostołów Chrystusa. Warto zauważyć, że wraz z Lidią ochrzciło się wielu innych, w większości jej współpracowników w handlu purpurą. W konsekwencji w Filippi powstała wspólnota tzw. Kościoła domowego, która gromadziła się na słuchaniu słowa w domu Lidii ${ }^{11}$.

9 Por. Pismo Święte Nowego Testamentu. Ewangelia według Świętego Łukasza, Wstęp, przekład z oryginału, komentarz, red. E. Dąbrowski, F. Gryglewicz, t. 3, cz. 3, Poznań-Warszawa 1974, s. 357.

10 Por. Katolicki komentarz biblijny, dz. cyt., s. 1228.

11 Por. Pismo Święte Nowego Testamentu. Dzieje Apostolskie, Wstęp, przekład z oryginału, komentarz, red. E. Dąbrowski, t. 5, Poznań 1961, s. 365-366. 


\subsection{Spotkanie św. Scholastyki z Benedyktem}

Spotkanie świętego rodzeństwa ukazuje wartość spraw duchowych. Jest to o tyle istotne, że spotkanie to ma walor ewangelizacyjny: wzajemne budowanie się, utwierdzanie w dobrych postawach i praktykach. Z pewnością w czasie tego spotkania nie zabrakło rozważania słowa Bożego w kontekście konkretnych doświadczeń przeżywanych przez św. Scholastykę i św. Benedykta.

„Scholastyka, siostra świętego Benedykta, od samego dzieciństwa poświęcona wszechmogącemu Bogu, miała zwyczaj raz w roku odwiedzać swojego brata. Mąż Boży przyjmował ją niedaleko poza bramą, w pomieszczeniu należącym do klasztoru.

Pewnego dnia przybyła według zwyczaju, a czcigodny brat wyszedł ku niej ze swymi uczniami. Cały dzień spędzili na modlitwie i świętych rozmowach, a kiedy zapadł zmrok, spożyli wspólnie posiłek ${ }^{12 "}$.

\subsection{Obiady ze św. Janem Pawłem II}

W sytuacji obiadów ze św. Janem Pawłem II nie mamy wątpliwości, że miały one walor ewangelizacyjny. Papież z Polski stwarzał taką atmosferę, że słowo Dobrej Nowiny mogło urabiać ludzkie serca. Spotkania te odbywały się przy posiłku, co też stanowi istotny element dla atmosfery ewangelizacyjnej, ma też znaczenie symboliczne.

Idąc pod prąd wielowiekowej tradycji, Jan Paweł II osobiście decydował, z kim będzie jadał posiłki. Niemal każdego dnia zapraszał gości na obiad. Zaproszeni odkrywali, że papież jest człowiekiem niezwykle bezpośrednim i naturalnym. W jego obecności nawet najbardziej nieśmiali i małomówni goście czuli się swobodnie. Papież był skupionym słuchaczem. Wydawało się, że jest bardziej zainteresowany tym, co ktoś chce mu powiedzieć, niż mówieniem tego, co chciałby sam przekazać. W ciągu pół godziny potrafił poprowadzić rozmowę od światowej polityki do tego, co się dzieje w domu parafialnym któregoś z gości;

12 Grzegorz Wielki, Dialogi, tłum. W. Szołdrski, Warszawa 1969, księga 2, 33. 
od pytań o intelektualistów, których kariery śledził, po pytania o dzieci współbiesiadnika ${ }^{13}$.

Powyżej przywołane zostały sytuacje biblijne i wybrane przykłady z życia świętych, z których widzimy, że ewangelizacja dokonuje się w czasie bezpośredniego spotkania z drugim człowiekiem. Natomiast warto podkreślić, że nieodzowne dla stworzenia właściwej sytuacji ewangelizacyjnej są pewne warunki, które stanowią o atmosferze spotkania i jego owocności. Do tych warunków można zaliczyć wzajemną otwartość, gotowość do słuchania i dzielenia się swoimi doświadczeniami i myślami. Musi też być przedmiot dzielenia się, a będzie to najczęściej przeżywana konkretnie sytuacja egzystencjalna. Na to wszystko można spojrzeć przez pryzmat słowa Bożego.

\section{Warunki zewnętrzne i wewnętrzne udanej wizyty domowej}

Niewątpliwie odwiedziny domowe, które mają stać się sytuacją, gdzie dokona się głoszenie Ewangelii, muszą spełniać pewne warunki. Chodzi o warunki zarówno zewnętrzne, jak i wewnętrzne. Wizyta kolędowa, która w pierwszym skojarzeniu przychodzi na myśl, gdy mowa o odwiedzinach domowych, ma pewne mankamenty. Funkcjonuje w wielu środowiskach jako coś koniecznego i wymuszonego, nie zawsze jako coś chcianego, pożądanego. Te mankamenty niestety sięgają także formuły wizyty kolędowej: w ograniczonym stosunkowo czasie trzeba odwiedzić sporą liczbę mieszkań. Efekt jest taki, że często wizyta kolędowa pozbawiona jest jakiegokolwiek waloru ewangelizacyjnego, a mogłaby być dobrą okazją do ewangelizacji. Abstrahujemy tutaj od kolędy. Odwiedziny domowe mogą mieć miejsce w różnych okresach roku i przy różnych okazjach. Może się zdarzyć, że powodem odwiedzin będzie choroba czy śmierć kogoś w konkretnej rodzinie. Powodem odwiedzin mogą też być inne okoliczności, jak chociażby chęć porozmawiania na tematy religijne.

13 Por. S. Dziwisz, Świadectwo, Warszawa 2007, s. 77 i 82. 


\subsection{Miejsce i czas}

Na pewno spotkanie, którego celem jest poruszenie głębszych treści wymaga spokojnej przestrzeni. Wykluczone jest wówczas towarzystwo zwierząt, z którymi domownicy na co dzień przebywają i często one stają się centrum uwagi w towarzystwie gości odwiedzających dom. Takie jest doświadczenie wielu proboszczów z wizyt duszpasterskich nazywanych kolędą. Podobnie trzeba powiedzieć o odbiorniku telewizyjnym. Często to on dosłownie i w przenośni „zagaduje” towarzystwo. Dodatkowym wyzwaniem są współcześnie wszechobecne telefony. Wiele osób nie wyobraża sobie, że można nie odebrać telefonu czy nie odpisać błyskawicznie na wiadomość tekstową, nawet podczas wizyty duszpasterza.

Spotkanie powinno odbywać się w miejscu, w którym domownicy jedzą wspólnie posiłki czy też spędzają wolny czas. Dobrze by było zasiąść do spotkania przy stole ${ }^{14}$. Stół jest w naszej cywilizacji ważnym elementem i w pewnym sensie narzędziem budowania relacji międzyludzkich. Wiele rzeczy w naszej kulturze dzieje się przy stole ${ }^{15}$. Ołtarz, na którym sprawuje się Eucharystię, to z całą swoją symboliką w istocie stół ${ }^{16}$. Ważny jest czas wybrany na spotkanie. To wszystko po to, żeby nikt się nie spieszył i miał pewien psychiczny komfort.

\subsection{Stworzenie dobrej atmosfery}

Nieważne jak poważnych spraw dotyczyć będzie cała rozmowa w jej najistotniejszych częściach, najważniejsze, aby rozmówcy czuli się partnerami w dialogu na równym poziomie. Wykluczone jest narzucanie poglądu czy opinii jednej strony. Otwartość na dialog i gotowość słuchania drugiej strony buduje właściwą atmosferę. Nikt nikogo nie powinien nawracać. Do stworzenia dobrej atmosfery może przyczynić się jakiś skromy poczęstunek, kawa, herbata. Po prostu stworzenie atmosfery

14 Por. Słownikjęzyka polskiego, red. W. Doroszewski, Warszawa 1966, s. 789.

15 Por. Britannica, ed. pol., t. 41, Poznań 1997, s. 49.

16 Por. D. Skrok, Stół Pański, w: Encyklopedia katolicka, t. 18, Lublin 2013, s. 994-995. 
przyjęcia i gościnności. Pomocą w wytworzeniu serdecznej atmosfery może też być opowiedzenie stosownego dowcipu czy anegdoty, które nikogo nie urażą, a wyeliminują nadmierny stres.

\subsection{Nastawienie wewnętrzne uczestników}

Niekiedy odwiedziny domowe mogą nosić znamiona czegoś, co dla świętego spokoju powinno się odbyć. Niejednokrotnie taką atmosferę wyczuwa się w czasie wizyty kolędowej, wręcz jakby domownicy na swoich twarzach mieli wymalowany komunikat: „dobrze by było, żeby już sobie poszedł, żeby to się już skończyło". Bywają tego typu uwarunkowania środowiskowe, jeśli chodzi o wizytę kolędową, że ktoś przyjmuje kolędę ze względu na opinię innych: krewnych, sąsiadów. Bywa też tak, że jeden z domowników jest otwarty na sprawy wiary, a inni nie. W takiej sytuacji pozostali domownicy będą zamknięci na jakiekolwiek treści religijne. Może się zdarzyć, że tylko jedna osoba będzie otwarta na podzielenie się swoim świadectwem życia i przyjęcie orędzia, z którym przyjdzie ewangelizator.

\section{Czym odwiedziny domowe nie powinny być}

Odwiedziny domowe nie mogą przyjąć charakteru poradnictwa w różnych dziedzinach życia. Nie może to być też rodzaj kierownictwa duchowego. Najczęściej tego rodzaju poradnictwo czy kierownictwo dotyczą indywidualnego spotkania z człowiekiem. Natomiast w wypadku odwiedzin domowych chodzi o spotkanie z rodziną, z domownikami, ze wspólnotą osób.

\section{Metodologia odwiedzin domowych}

W średniowiecznych klasztorach znana była praktyka tak zwanych collatio. Polegała ona na tym, że mnisi gromadzili się po nieszporach na słuchanie budującego fragmentu życiorysu świętych bądź obszerniejszego 
passusu z historii ksiąg Starego Testamentu ${ }^{17}$. Chodziło o umocnienie się na drodze wiary i utwierdzenie w podejmowanych duchowych wysiłkach poprzez przykłady z życia ludzi wymienionych w Biblii bądź też zaczerpnięte z życia świętych. Nawiązanie do tej praktyki pozwala podjąć próbę zarysowania pewnej metodologii odwiedzin domowych i wskazanie najważniejszych elementów, które sprzyjają „domowej ewangelizacji”.

Pewnych podpowiedzi co do metodologii odwiedzin domowych dostarczają założenia kursu Alpha. Z tym jednak, że w wypadku odwiedzin domowych mamy sytuację, kiedy osoba ewangelizatora przychodzi do konkretnych osób w ich miejscu zamieszkania. Kurs Alpha zakłada sytuację, w której osoby zainteresowane poszerzeniem informacji na temat chrześcijańskich zasad wiary same przychodzą na spotkanie w określonym czasie i miejscu. Kto chce, może przyjść. Kurs jest adresowany do tych, którzy chcą się dowiedzieć czegoś więcej na temat wiary chrześcijańskiej niezależnie od wyznania czy wieku. Kurs składa się z 15 tematów dotykających podstawowych zagadnień wiary chrześcijańskiej. Spotkania odbywają się w radosnej atmosferze. Ważnym elementem spotkania jest spożywanie posiłku, choćby symbolicznego. Daje to uczestnikom okazję do poznania siebie i budowania przyjacielskich relacji. Istotnym elementem spotkania jest możliwość zadawania pytań. Mniejsze grupy stwarzają do tego doskonałą sytuację ${ }^{18}$.

Punktem wyjścia odwiedzin domowych powinno być doświadczenie życiowe naświetlone słowem Bożym. Poznajemy sytuację ludzi oferujących gościnę w rozmowie, która toczy się w pierwszej części odwiedzin domowych. Zyskujemy informacje na temat aktualnej sytuacji odwiedzanych i ich doświadczeń, którymi w tym momencie żyją. Może to być bardzo zwyczajna codzienna egzystencja, bez szczególnych wydarzeń, ale to jest też konkretna sytuacja egzystencjalna. Często może być tak, że spotkamy ludzi, którzy nie mają nic przeciw Kościołowi i Ewangelii, ale mają jednocześnie bardzo swobodną relację z Kościołem i niewielką znajomość Ewangelii. To też konkretna sytuacja egzystencjalna, którą

17 Por. J. Kopeć, Collatio, w: Encyklopedia katolicka, t. 3, red. R. Łukaszyk, L. Bieńkowski, F. Gryglewicz, Lublin 1979, s. 540.

18 Por. http://polska.alpha.org/how-to-run-alpha (14.09.2017). 
warto zobaczyć w świetle słowa Bożego. Tak więc pierwsza zasada metodologii odwiedzin domowych to naświetlenie sytuacji egzystencjalnej przez słowo Boże. Co do dynamiki odwiedzin domowych, to trzeba pamiętać, że często będą się one cechowały dużą spontanicznością i będą zawierały elementy nieprzewidywalne, jak chociażby pytania, które zrodzą się w uczestnikach pod wpływem usłyszanych słów, atmosfery oraz doświadczenia, które aktualnie przeżywają. Warto zaproponować w tym miejscu prostą metodologię odwiedzin domowych:

- głoszenie słowa Bożego w świetle konkretnie zaistniałej sytuacji egzystencjalnej. To może być krótki fragment, werset biblijny, ale odnajdujący odwiedzanych ludzi w ich sytuacji życiowej.

- rozmowa o tym, co czujemy i jakie rodzą się w nas pytania i jakie rozterki.

- owoc, czyli próba wlania nadziei w serca słuchaczy albo utwierdzenia tego, w czym trwają. Chodzi o dobre cechy, postawy, praktyki.

Takie odwiedziny domowe mogą być owocne i bezowocne w sensie zachęcenia kogoś do życia według Ewangelii Chrystusa. Próba ewangelizowania w czasie odwiedzin domowych może wręcz zaowocować buntem kogoś, kto usłyszy konkretne słowo, konkretne wymagania i nie będzie chciał tego przyjąć. Trzeba się przygotować na różne sytuacje.

Podsumowując całość rozważań nad odwiedzinami domowymi jako miejscem głoszenia Ewangelii Chrystusa, warto zauważyć, że w poszukiwaniu człowieka, który znajduje się na peryferiach ewangelizacji, należałoby dowartościować spotkanie. Chodzi o takie sytuacje, w których konkretny człowiek będzie czuł się potraktowany bardzo indywidualnie, będzie czuł, że to do niego jest adresowane to konkretne głoszenie słowa Bożego. 


\section{Summary}

\section{Odwiedziny domowe jako okazja do głoszenia Ewangelii Chrystusa}

Współczesny człowiek jest dumny z różnych osiągnięć cywilizacyjnych, w tym także na poziomie środków i narzędzi międzyludzkiej komunikacji. To wszystko jednak nie zastąpi osobistego spotkania człowieka z drugim człowiekiem. Nie ma wątpliwości, że spotkanie to fundamentalne doświadczenie w budowaniu relacji międzyludzkich. Okazją do takiego spotkania są odwiedziny domowe. W artykule podjęty został temat możliwości głoszenia Ewangelii w sytuacji odwiedzin domowych. W poszczególnych częściach artykułu ukazane zostały miejsca biblijne, które mówią o odwiedzinach domowych z udziałem Jezusa i apostołów. W tym samym kontekście przytoczone zostały przykłady z życia wybranych świętych. W artykule podjęta została także próba określenia metodologii odwiedzin domowych.

Słowa kluczowe: odwiedziny domowe, spotkanie, głoszenie Ewangelii, metodologia odwiedzin domowych

\section{Home Visits as an Occasion for Proclaiming the Gospel of Christ}

Modern society is proud of the various achievements of civilization, including the various technologies that facilitate interpersonal communication. These, however, do not replace personal encounters, face-to-face. There is no doubt that meeting in person is a fundamental experience in building interpersonal relationships. Home visits are opportunities for such meetings. This article explores the possibility of proclaiming the Gospel in the context of home visits. Specific sections indicate references from the Bible where Jesus' home visits are mentioned. In the same context, the article also presents situations from the lives of chosen saints. Finally, the article also attempts to define a methodology of home visits.

Keywords: home visit, meeting, preaching the Gospel, home visit methodology

\section{Bibliografia}

Britannica, ed. pol., t. 41, Poznań 1997.

Dziwisz S., Świadectwo, Warszawa 2007.

Grzegorz Wielki, Dialogi, tłum. W. Szołdrski, Warszawa 1969.

http://polska.alpha.org/how-to-run-alpha (14.09.2017).

Janowski P., Kolęda, wizyta duszpasterska, w: Encyklopedia katolicka, t. 9, red. A. Bednarek i in., Lublin 2002, s. 349. 
Kamiński R., Kolęda, w: Leksykon teologii pastoralnej, red. R. Kamiński, W. Przygoda, M. Fiałkowski, Lublin 2006, s. 384-385.

Katolicki komentarz biblijny, red. R. E. Brown, J. A. Fitzmyer, R. E. Murphy, red. nauk. wyd. pol. W. Chrostowski, Warszawa 2001.

Kodeks prawa kanonicznego, przekł. polski, Poznań 1984.

Kopeć J., Collatio, w: Encyklopedia katolicka, t. 3, red. R. Łukaszyk, L. Bieńkowski, F. Gryglewicz, Lublin 1979, s. 540.

Pismo Święte Nowego Testamentu. Dzieje Apostolskie. Wstęp, przekład z oryginału, komentarz, red. E. Dąbrowski, t. 5, Poznań 1961.

Pismo Święte Nowego Testamentu. Ewangelia Według Świętego Łukasza, Wstęp, przekład $z$ oryginału, komentarz, red. E. Dąbrowski, F. Gryglewicz, t. 3, cz. 3, Poznań-Warszawa 1974.

Skrok D., Stót Pański, w: Encyklopedia katolicka, t. 18, red. E. Gigilewicz i in., Lublin 2013, s. 994-995.

Słownikjęzyka polskiego, red. W. Doroszewski, Warszawa 1966. 